\title{
Stimulation of glycoprotein and protein synthesis in isolated pig gastric mucosal cells by prostaglandins
}

\author{
H-K Heim, A Oestmann, K-Fr Sewing
}

\begin{abstract}
The purpose of this study is to evaluate the effects of different prostaglandin derivatives on protein and glycoprotein synthesis and secretion in isolated and enriched pig gastric mucous cells, as measured by the incorporation of $\left[{ }^{3} \mathbf{H}\right] \mathrm{L}$-leucine and $\mathbf{N}$-acetyl-[ $\left[{ }^{14} \mathrm{C}\right] \mathrm{D}$-glucosamine respectively into acid insoluble macromolecules (AIM). $\mathrm{PGE}_{2}$ and 16,16dimethyl-PGE 2 enhanced the incorporation of the amino sugar into cellular $\left(E_{50} 8\right.$ and $75 \mathrm{nmol} / \mathrm{l})$ and secreted $\left(\mathrm{EC}_{50} 30\right.$ and $270 \mathrm{nmol} / \mathrm{l}) \mathrm{AIM}$ in a concentration dependent manner during a 20 hours incubation. After incubation for eight hours or more they also stimulated the incorporation of $\left[{ }^{3} \mathrm{H}\right] \mathrm{L}$-leucine into cellular AIM. PGF $2 \alpha$ was considerably less potent $\left(\mathrm{EC}_{50}>1 \mu \mathrm{mol} / \mathrm{l}\right)$ than the E-type prostaglandins. Iloprost, a stable prostacyclin analogue, was ineffective.
\end{abstract}

Production of mucus, especially the synthesis and secretion of gel forming, high molecular weight glycoproteins, is one of the major physiological functions of the stomach ${ }^{1}$ and prostaglandins are known to enhance this process in vivo. ${ }^{2}$ It remains unclear, however, whether this is caused by a direct effect of prostaglandins on the gastric mucous cells, because indirect effects, resulting from the cellular heterogeneity of the gastric mucosa and from possible interferences with other neuronal or humoral regulation systems, cannot be ruled out in in vivo studies. To avoid this problem, mucus production was examined directly at the cellular level, ${ }^{3}$ showing that isolated and enriched pig gastric mucous cells synthesise proteins and glycoproteins in suspension culture for up to 20 hours of incubation, as measured by the incorporation of $\left[{ }^{3} \mathrm{H}\right]$ L-leucine $\left(\left[{ }^{3} \mathrm{H}\right]\right.$ Leu $)$ and $\mathrm{N}$-acetyl- $\left[{ }^{1+} \mathrm{C}\right] \mathrm{D}$ glucosamine $\left(\left[{ }^{1+} \mathrm{C}\right] \mathrm{GlcNAc}\right)$ respectively into trichloroacetic acid/phosphotungstic acid (TCA/ PTA) insoluble macromolecules (AIM). The aim of the present study was to evaluate the time and concentration dependence of prostaglandin effects on these parameters and to examine possible differences in the potency and efficacy between $\mathrm{PGE}_{2}$, 16,16-dimethyl-PGE 2 (16,16diM-PGE 2$), \mathrm{PGF}_{2 \alpha}$, and the stable prostacyclin analogue iloprost.

\section{Methods}

CELL PREPARATION

Cells were prepared by using a slight modification of the method of Mardh et al. ${ }^{+}$In brief, ${ }^{3}$ gastric mucosal cells were isolated from pig corpus mucosa by successive treatment with pronase and collagenase. Cell separation was achieved by counterflow centrifugation, using a Beckman elutriator rotor on a Beckman J-6 centrifuge, resulting in four cell populations (F1-F4). For this we used F2 cells, consisting of about $54 \%$ mucous cells, $42 \%$ chief cells and $4 \%$ parietal cells, as determined by cell staining, ${ }^{3}$ in a concentration of $2 \times 10^{6}$ cells $/ \mathrm{ml}$. Cell viability, as checked by trypan blue exclusion, was $>90 \%$.

\section{INCORPORATION OF RADIOACTIVE}

TRACERS

As previously described, ${ }^{3}$ cells were incubated in Dulbecco's modified Eagle's medium, containing HEPES $25 \mathrm{mmol} / 1$ instead of $\mathrm{NaHCO}_{3}$, L-leucine $10 \mu \mathrm{mol} / \mathrm{l}$, bovine serum albumin $1 \mathrm{mg} / \mathrm{ml}$, penicillin $100 \mathrm{IU} / \mathrm{ml}$, streptomycin $100 \mu \mathrm{g} / \mathrm{ml}$ and indometacin $10 \mu \mathrm{mol} / \mathrm{l}$. Cell suspensions $(1.8 \mathrm{ml})$ were incubated in uncapped vials in a shaking water bath at $37^{\circ} \mathrm{C}$ in the presence of $0.028 \mu \mathrm{Ci} / \mathrm{ml}\left[{ }^{3} \mathrm{H}\right] \mathrm{Leu}$ and $0.278 \mu \mathrm{Ci} / \mathrm{ml}\left[{ }^{1+} \mathrm{C}\right] \mathrm{GlcNAc}$ and the test substances to be studied. Iloprost was purchased as a $1.4 \mathrm{mmol} / \mathrm{l}$ aqueous solution. The other prostaglandins were dissolved at a concentration of $10 \mathrm{mmol} / \mathrm{l}$ in ethanol $100 \%$. All prostanoids were diluted with $\mathrm{H}_{2} \mathrm{O}$ to the required concentrations immediately before use and added in a volume of $18 \mu \mathrm{l}$. Appropriate controls were run with ethanol, which had significant effects only in a concentration of $1 \%$, corresponding to the concentration contained in the samples treated with prostaglandins $100 \mu \mathrm{mol} / \mathrm{l}$. At the times indicated, cellular and secreted AIM were separated by centrifugation and precipitated by TCA/PTA (final concentration $10 \% / 1 \%$ ). The samples were left at $4^{\circ} \mathrm{C}$ overnight, washed thoroughly, and then solubilised in $1 \mathrm{ml} \mathrm{KOH} 0.6 \mathrm{~mol} / \mathrm{l}$. Incorporated radioactivity was determined in a LKB 1217 rackbeta liquid scintillation counter, using quench correction programmes for ${ }^{3} \mathrm{H}$ and ${ }^{1+} \mathrm{C}$ labelled samples, and was expressed as $\mathrm{dpm} / 10^{6}$ cells after correcting for unspecific trapping by the incubation medium.

\section{STATISTICAL ANALYSIS}

Analysis of variance $e^{5}$ and subsequently Dunnett's $t$ test $^{6}$ were used to compare the mean values of different treatments. Differences with a $\mathrm{p}<0.05$ were considered to be significant. Results were expressed as mean (SEM). EC 50 values were estimated graphically. Correlation coefficients were calculated by linear regression.

\section{SUBSTANCES}

Collagenase type I and V, Dulbecco's modified Eagle's medium deficient in L-leucine, penicil- 

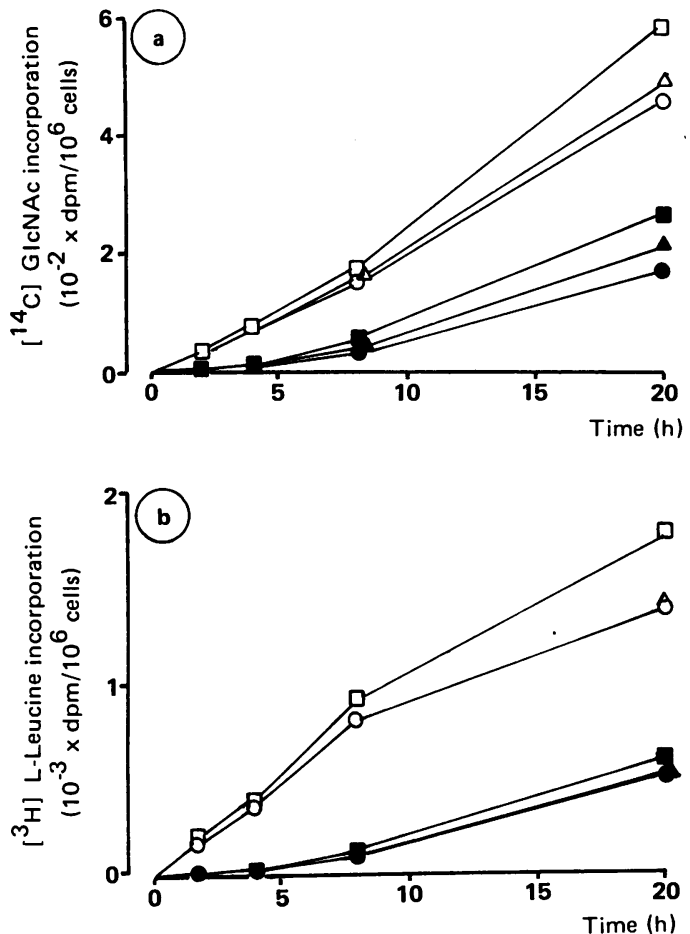

Figure 1: Time course of the incorporation of $(a)$ $\left[^{1+} \mathrm{C} J \mathrm{GlcN} A \mathrm{c}\right.$ and $(\mathrm{b})\left[^{3} \mathrm{H}\right] \mathrm{Leu}$. Isolated gastric cells were incubated with the tracers for the indicated times without $(\mathrm{O}, \mathrm{)})$ or with $P G E_{2} 1 \mu \mathrm{mol} / \mathrm{l}(\square, \mathbf{\square})$ or $P G F_{2 \alpha} 1 \mu \mathrm{mol} / \mathrm{l}$ $(\triangle, \mathbf{\Delta})$ and activity incorporated into cellular (open symbols) and suspension medium (closed symbols) AIM was determined as described under methods. Each value represents the mean of 12 separate incubations, obtained for both prostaglandins concurrently in four different cell preparations. SEM were omitted for reasons of clarity.

lin-streptomycin solution $(10000 \mathrm{IU} / \mathrm{ml}$, $10 \mathrm{mg} / \mathrm{ml}$ ), $\mathrm{PGE}_{2}, \mathrm{PGF}_{2 \alpha}$ [Sigma, München, FRG]; 16,16-diM-PGE 2 [Upjohn, Kalamazoo, Michigan, USA]; iloprost [Schering, Berlin]; bovine serum albumin, HEPES [Serva, Heidelberg, FRG]; [4,5-3 $\mathrm{H}] \mathrm{L}$-leucine spec. act. $140 \mathrm{Ci} / \mathrm{mmol}$ in $2 \%$ ethanol, $\mathrm{N}$-acetyl- $\left[1-{ }^{1+} \mathrm{C}\right]$
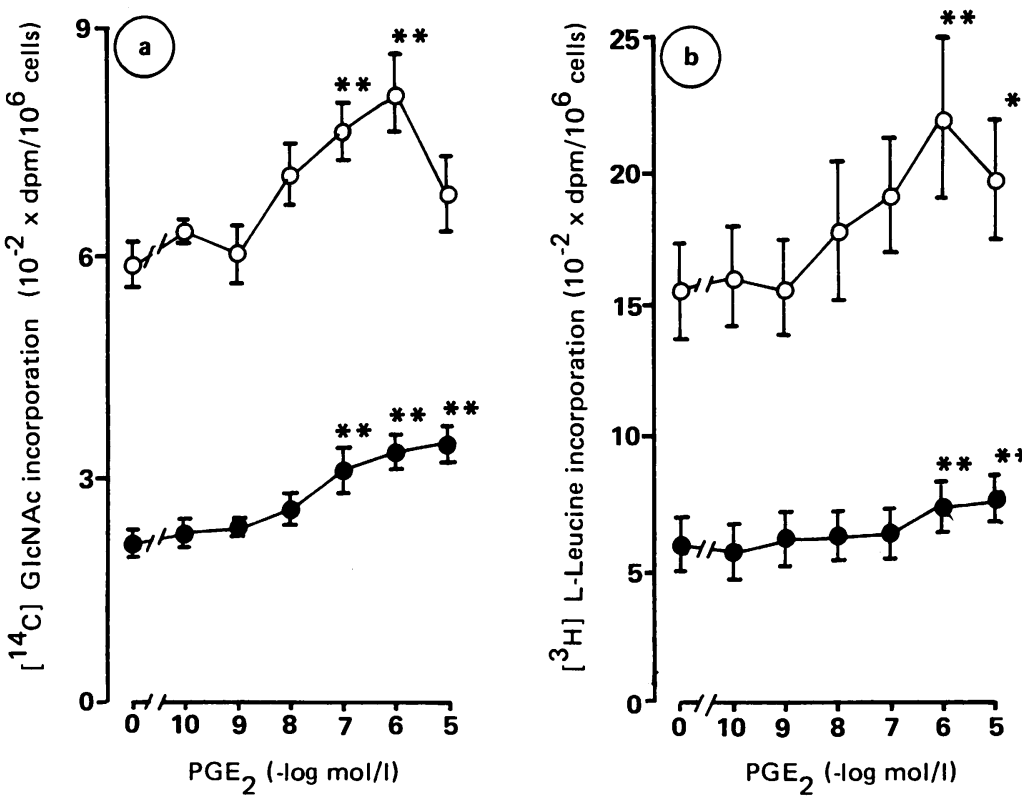

Figure 2: Effect of $P G E_{2}$ on the incorporation of $(a)\left[{ }^{14} \mathrm{C}\right] G l c N A c$ and $(b)\left[{ }^{3} \mathrm{H}\right]$ Leu after $20 \mathrm{~h}$ of incubation. Isolated gastric cells were incubated with the tracers and $P G E_{2}$ in the concentrations indicated and activity incorporated into cellular $(\bigcirc)$ and suspension medium (O) AIM was determined as described under methods. Each value represents the mean $(S E M)$ of eight separate incubations, obtained in three different cell preparations. ${ }^{\star}=p<0 \cdot 05$ $\star \star=p<0.01$ versus control.
D-glucosamine spec. act. $58 \cdot 7 \mathrm{mCi} / \mathrm{mmol}$ in $2 \%$ ethanol [Amersham, Braunschweig, FRG]; indometacin sodium trihydrate [Merck, Sharp and Dohme, Rahway, USA]. All other substances were of analytical grade by Merck [Darmstadt, FRG].

\section{Results}

TIME COURSE OF THE EFFECTS OF PGE AND PGF 20

The basal incorporation of $\left[{ }^{14} \mathrm{C}\right] \mathrm{GlcNAc}$ (Fig la) and $\left[{ }^{3} \mathrm{H}\right]$ Leu (Fig $\mathrm{lb}$ ) into cellular AIM $(r=0.998$ and $r=0.979)$ and that secreted into the suspension medium $(r=0.988$ and $r=0.992)$ proceeded up to 20 hours in an almost linear fashion. $\mathrm{PGE}_{2} 1 \mu \mathrm{mol} / \mathrm{l}$ enhanced the incorporation of $\left[{ }^{1+} \mathrm{C}\right] \mathrm{GlcNAc}$ into cellular and suspension medium AIM throughout the 20 hour incubation, whereas $\mathrm{PGF}_{2 \alpha} 1 \mu \mathrm{mol} / 1$ was without significant effect. A distinct stimulation of the incorporation of $\left[{ }^{3} \mathrm{H}\right] \mathrm{Leu}$ into cellular and suspension medium AIM under $\mathrm{PGE}_{2}$ could be detected only after an incubation of eight hours or more. Again $\mathrm{PGF}_{2 \alpha}$ was without significant effect throughout the incubation.

\section{CONCENTRATION DEPENDENCE OF PROSTAGLANDIN EFFECTS}

$P G E_{2}$

After 20 hours of incubation $\mathrm{PGE}_{2}$ enhanced the incorporation of $\left[{ }^{1+} \mathrm{C}\right] \mathrm{GlcNAc}$ (Fig 2a) and $\left[{ }^{3} \mathrm{H}\right]$ Leu (Fig 2b) into cellular AIM (EC ${ }_{50} 8$ and $50 \mathrm{nmol} / \mathrm{l}$ ) and that secreted into the suspension medium $\left(\mathrm{EC}_{50} 30\right.$ and $\left.200 \mathrm{nmol} / \mathrm{l}\right)$ in a concentration dependent manner. $\mathrm{PGE}_{2}$ produced maximal stimulation of $\left[{ }^{1+} \mathrm{C}\right] \mathrm{GlcNAc}$ and $\left[{ }^{3} \mathrm{H}\right] \mathrm{Leu}$ incorporation into cellular (39\%, $\mathrm{p}<0.01$ and $42 \%, \mathrm{p}<0.01)$ AIM at $1 \mu \mathrm{mol} / \mathrm{l}$, whereas incorporation into AIM secreted into the suspension medium $(61 \%, \mathrm{p}<0.01$ and $29 \%$, $\mathrm{p}<0.01$ ) was maximal at $10 \mu \mathrm{mol} / \mathrm{l}$.

\section{6,16-diM-PGE}

After 20 hours of incubation, 16,16-diM-PGE enhanced the incorporation of $\left[{ }^{14} \mathrm{C}\right] \mathrm{GlcNAc}$ (Fig 3a) and [ $\left.{ }^{3} \mathrm{H}\right]$ Leu (Fig $\left.3 b\right)$ into cellular $\left(\mathrm{EC}_{50}\right.$ 75 and $130 \mathrm{nmol} / \mathrm{l}$ ) AIM in a concentration dependent manner, with a maximal stimulation of $45 \%(\mathrm{p}<0.01)$ and $53 \%(\mathrm{p}<0.01)$ respectively at $1 \mu \mathrm{mol} / 1$. Incorporation of $\left[{ }^{14} \mathrm{C}\right] \mathrm{GlcNAc}$ into AIM secreted into the suspension medium $\left(\mathrm{EC}_{50}\right.$ $270 \mathrm{nmol} / \mathrm{l}$ ) was stimulated maximally by $32 \%$ at $10 \mu \mathrm{mol} / \mathrm{l}$, however, no significant effect on the corresponding $\left[{ }^{3} \mathrm{H}\right]$ Leu activity was detectable. Concentration response curves were bell shaped and 16,16-diM-PGE $100 \mu \mathrm{mol} / \mathrm{l}$ significantly inhibited the $\left[{ }^{14} \mathrm{C}\right] \mathrm{GlcNAc}$ incorporation into cellular and secreted AIM and the amount of secreted acid-precipitable $\left[{ }^{3} \mathrm{H}\right]$ Leu activity.

Although the prostaglandin enhanced the incorporation of $\left[{ }^{14} \mathrm{C}\right] \mathrm{GlcNAc}$ (Fig 4a) into cellular AIM also after four hours of incubation $\left(\mathrm{EC}_{50} 80\right.$ $\mathrm{nmol} / \mathrm{l})$, maximally by $37 \%(\mathrm{p}<0.01)$ at 10 $\mu \mathrm{mol} / \mathrm{l}$, no significant stumulation of $\left[{ }^{3} \mathrm{H}\right] \mathrm{Leu}$ (Fig 4b) incorporation into cellular and suspen- 

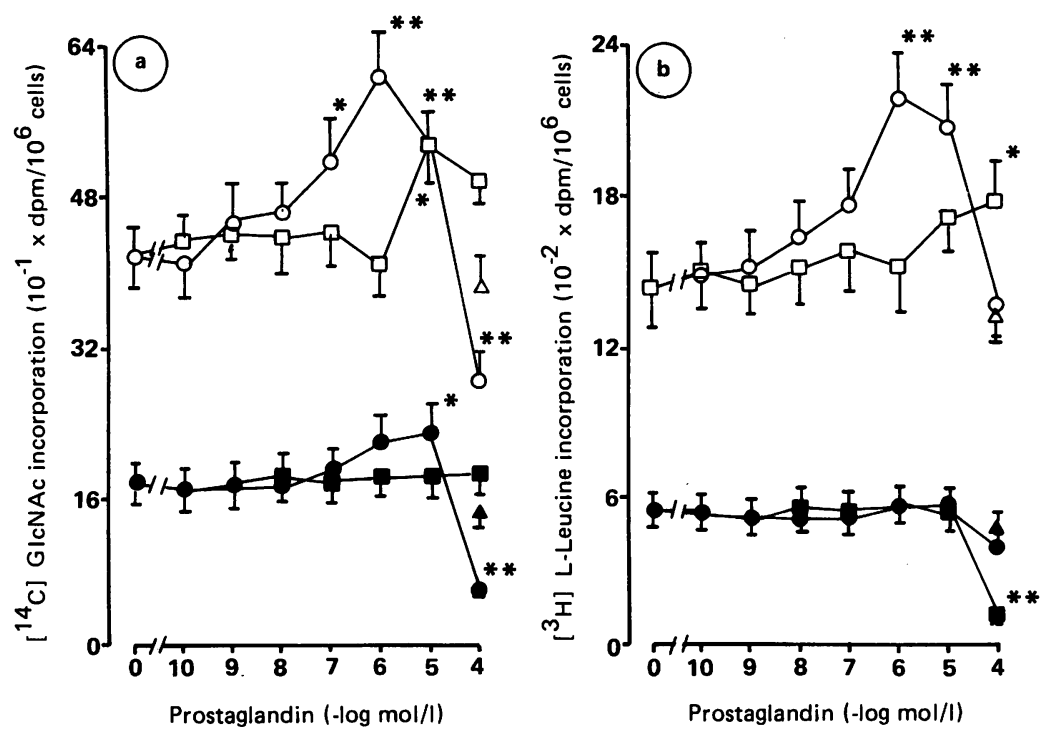

Figure 3: Effects of 16,16-diM-PGE $(\mathrm{O}, \mathrm{O})$ and $P G F_{2 \alpha}(\square, \square)$ on the incorporation of (a) $\left[{ }^{14} \mathrm{C} J \mathrm{GlcNAc}\right.$ and $(\mathrm{b})$ [ $\left.\mathrm{B} H\right]$ Leu after $20 \mathrm{~h}$ of incubation. Isolated gastric cells were incubated with the tracers and the prostaglandins in the concentrations indicated and activity incorporated into cellular (open symbols) and suspension medium (closed symbols) AIM was determined as described under methods $(\triangle, \Delta)$ depicts samples treated with ethanol $1 \%$ alone. Each value represents the mean (SEM) of 12 separate incubations, obtained for both prostaglandins concurrently in 4 different cell preparations. ${ }^{\star}=p<0.05, \star \star=p<0.01$ versus control.

sion medium AIM was detectable after this shorter incubation.

$P G F_{2 \alpha}$

After 20 hours of incubation $\mathrm{PGF}_{2 \alpha}$ had significant effects on the incorporation of $\left[{ }^{14} \mathrm{C}\right] \mathrm{GlcNAc}$ (Fig 3a, 27\%, p $<0.05$ ) and $\left[{ }^{3} \mathrm{H}\right]$ Leu (Fig 3b, $24 \%, \mathrm{p}<0.05$ ) into cellular AIM only in concentrations of $10 \mu \mathrm{mol} / \mathrm{l}$ and $100 \mu \mathrm{mol} / \mathrm{l}$ respectively and failed to enhance the incorporation of the tracers into secreted AIM.

After four hours of incubation the prostaglandin enhanced the incorporation of $\left[{ }^{1+} \mathrm{C}\right]$ GlcNAc (Fig 4a) into cellular AIM again in a
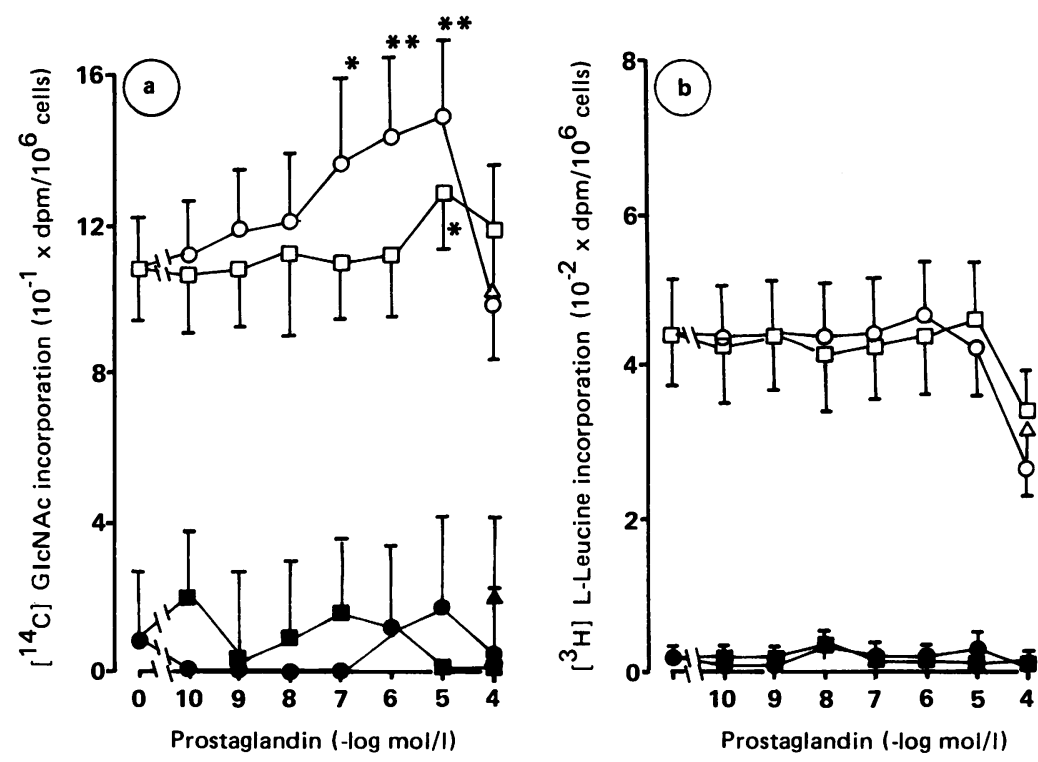

Figure 4: Effects of 16,16-diM-PGE $(O, \bigcirc)$ and $P G F_{2, u}(\square, \square)$ on the incorporation of (a) $\left[{ }^{1+} \mathrm{C} / \mathrm{Gl}\right.$ NA $\mathrm{c}$ and $(\mathrm{b})$ ['H]Leu after $4 \mathrm{~h}$ of incubation. Isolated gastric cells were incubated with the tracers and the prostaglandins in the concentrations indicated and activity incorporated into cellular (open symbols) and suspension medium (closed symbols) AIM was determined as described under methods. $(\triangle, \Delta)$ depicts samples treated with ethanol $1 \%$ alone. Each value represents the mean (SEM) of 12 separate incubations, obtained for both prostaglandins concurrently in 4 different cell preparations. ${ }^{\star}=p<0.05,{ }^{\star}=p<0.01$ versus control. concentration of $10 \mu \mathrm{mol} / \mathrm{l}(19 \%, \mathrm{p}<0.05)$ but had no significant stimulatory effect on the incorporation of $\left[{ }^{3} \mathrm{H}\right]$ Leu (Fig 4b).

\section{Iloprost}

After 20 hours of incubation iloprost had no significant effects on the incorporation of the tracers into cellular and secreted AIM in concentrations ranging from $100 \mathrm{pmol} / \mathrm{l}$ to $10 \mu \mathrm{mol} / \mathrm{l}$ (Fig 5).

\section{Discussion}

Prostaglandins are synthesised ubiquitously in the body and exert a variety of biological effects. The spectrum and relative amount of different prostaglandin derivatives produced, as well as their rank order of potency ${ }^{8}$ however, may vary from one tissue to another. The latter seems to be the result of the existence of different prostaglandin receptors. ${ }^{9}$

In the stomach in vivo experiments indicated a stimulation of mucous glycoprotein production by PGE and PGF derivatives and this has been related to their protective effect on the gastric mucosa against various noxious agents. ${ }^{2}$ E-type prostaglandins also had trophic effects as reflected in an increase in weight of the gastric mucosa, ${ }^{10-13}$ suggesting an additional influence on overall protein synthesis. Because of the cellular heterogeneity of the gastric mucosa, however, it remained unclear if these stimulations resulted from direct effects on the gastric mucous cells or were because of interactions with neuronal or humoral regulatory systems located on other cell types. To avoid these difficulties inherent to in vivo studies, we evaluated the potency and efficacy of $\mathrm{PGE}_{2}, 16,16-\mathrm{diM}-\mathrm{PGE}_{2}$, $\mathrm{PGF}_{2 \alpha}$ and iloprost, a stable prostacyclin analogue, on protein and glycocprotein production directly at the cellular level, by using isolated and enriched pig gastric mucous cells.

\section{GLYCOPROTEIN PRODUCTION}

Besides their in vivo effects, E-type prostaglandins enhanced incorporation of $\left[{ }^{1+} \mathrm{C}\right] \mathrm{GlcNAc}$ and $\left[{ }^{3} \mathrm{H}\right]$ glucosamine, both amino sugar precursors of glycoproteins, in vitro into cellular AIM of isolated $^{14}$ or cultured ${ }^{15}$ rat gastric mucosal cells. Although in these investigations stimulations were achieved only with supraphysiological concentrations of the prostanoids as high as 100 and $3 \mu \mathrm{mol} / \mathrm{l}$ respectively, a possible physiological function of prostaglandins in the regulation of glycoprotein synthesis was supported by an enhanced incorporation of $\left[{ }^{3} \mathrm{H}\right]$ glucosamine by cultured rat gastric cells in presence of the prostaglandin precursor arachidonic acid. ${ }^{16}$ In the present paper we could show by using enriched gastric mucous cells, that the E-type prostaglandins $\mathrm{PGE}_{2}$ and 16,16diM-PGE ${ }_{2}$ enhance the incorporation of $\left[{ }^{1+} \mathrm{C}\right] \mathrm{GlcNAc}$ into cellular and secreted AIM concentration dependently already in the nanomolar range and that this stimulation is detectable throughout a 20 hour incubation. In regard of the specificity of this effect for different prostaglandin derivatives, we could show that 

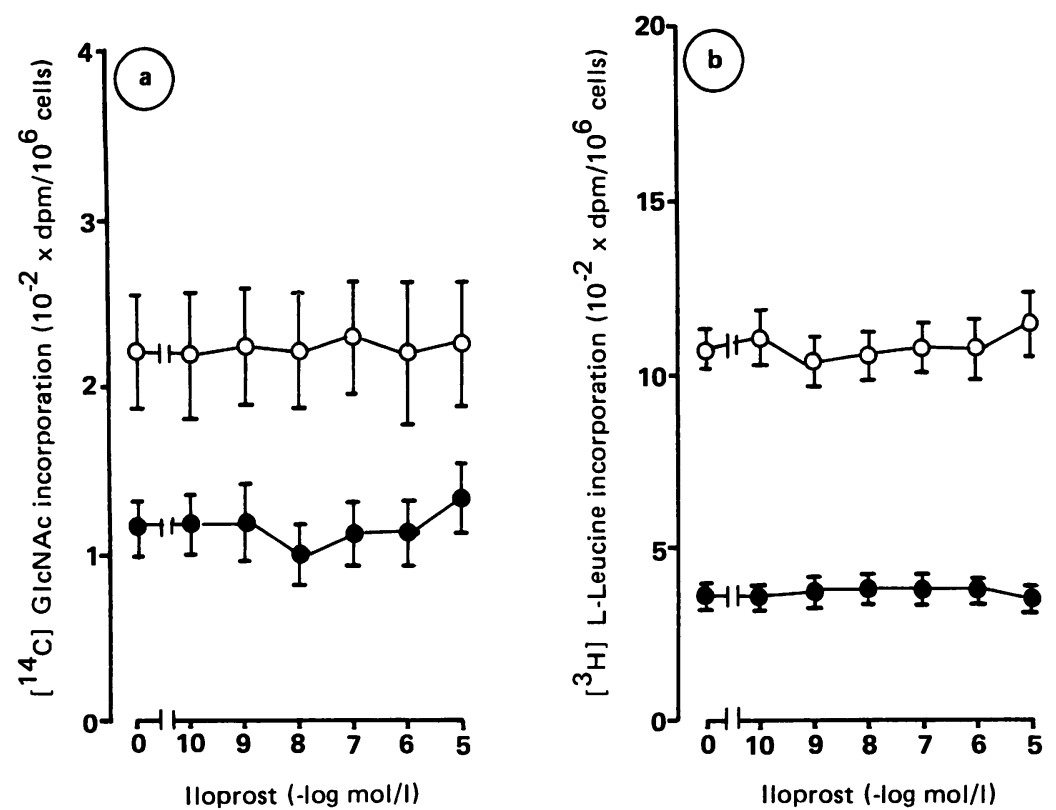

Figure 5: Effect of iloprost on the incorporation of $(a)\left[{ }^{1+} \mathrm{C} / G l c N A c\right.$ and $(b)\left[{ }^{3} \mathrm{H}\right] \mathrm{Leu}$ after $20 \mathrm{~h}$ of incubation. Isolated gastric cells were incubated with the tracers and iloprost in the concentrations indicated and activity incorporated into cellular $(O)$ and suspension medium (O) AIM was determined as described under methods. Each value represents the mean $(S E M)$ of 15 separate incubations, obtained in five different cell preparations.

$\mathrm{PGF}_{2 \alpha}$ is less potent $\left(\mathrm{EC}_{50}>1 \mu \mathrm{mol} / \mathrm{l}\right)$ and efficacious and that the stable prostacyclin analogue iloprost is ineffective in concentrations up to $10 \mu \mathrm{mol} / \mathrm{l}$. This is in accordance with a study in which 16,16 -diM-PGE 2 was also more potent than $\mathrm{PGF}_{2 \alpha}$ in stimulating the secretion of prelabelled glycoproteins from gastric mucosal explants of the rabbit gastric mucosa, although both prostaglandins failed to enhance glycoprotein synthesis in this investigation. ${ }^{17}$

\section{PROTEIN PRODUCTION}

Data on the in vivo effect of prostaglandins on overall protein synthesis are scarce. An autoradiographic investigation in the rat indicated that $16,16-$ diM-PGE $_{2}$ had no effect on incorporation of $\left[{ }^{3} \mathrm{H}\right]$ serine into proteins after one hour of treatment, but that it enhanced the incorporation of the labelled amino acid by surface mucous cells after seven days of treatment by $80 \%$, although the authors refused to accept this increase as significant. ${ }^{18}$ In in vitro experiments, an enhanced incorporation of labelled amino acids under 16,16-diM-PGE 2 or $\mathrm{PGE}_{2}$ was found by Tsukada $e t$ al,${ }^{19}$ using a crude cell preparation of the rat stomach, and by Bersimbaev et $a l^{14}$ working with isolated rat gastric mucosal cells, although in the latter study stimulation required the high concentration of $100 \mu \mathrm{mol} / 1$ of the prostanoid. In our investigation the E-type prostaglandins enhanced cellular protein synthesis already in the nanomolar range. Although a distinct stumulation of the incorporation of [ $\left.{ }^{3} \mathrm{H}\right] \mathrm{Leu}$ into cellular AIM by $\mathrm{PGE}_{2}$ and 16,16 diM-PGE 2 was only detectable after eight hours or more of incubation and $\mathrm{EC}_{50}$ values seemed to be higher than that for stimulation of glycoprotein synthesis, the specificity of this effect was the same as that for $\left[{ }^{14} \mathrm{C}\right] \mathrm{GlcNAc}$ incorporation, as iloprost was again ineffective and $\mathrm{PGF}_{2 \alpha}$ was less potent and efficacious than the E-type prostaglandins. These in vitro results are in accordance with an in vivo investigation, in which prostacyclin and the stable prostacyclin derivative Hoe 982 failed to enhance the growth of rat gastric mucosa, whereas PGE and PGF derivatives were effective. ${ }^{13}$

Our results suggest that stimulation of glycoprotein and protein synthesis and secretion are PGE receptor mediated processes. This view is supported by the demonstration of specific PGE binding sites in homogenates of pig ${ }^{20-22}$ and on isolated cells of canine ${ }^{23}$ and rat ${ }^{14}$ gastric mucosa. No specific binding sites for F-type prostaglandins could be detected ${ }^{24}$ and binding sites for I-type prostaglandins ${ }^{25}$ are at least controversial. ${ }^{26}$ Our results offer no clues how the prostaglandins stimulate glycoprotein and protein synthesis. The underlying mechanism(s) as well as the nature of the synthesised radiolabelled products remain to be evaluated. Stimulation does not seem to be inevitably related to an increase in DNA synthesis, however, ${ }^{11}{ }^{27-29}$ cell turnover,,$^{30}$ or cell number ${ }^{12}$ in the gastric mucosa. Cyclic AMP may be a possible intracellular 'second messenger' for the prostaglandins, although the physiological importance of the reported stimulations ${ }^{1431}$ remains to be established.

From the stimulatory actions of $\mathrm{PGE}_{2}$ and $16,16-d i M-P G E_{2}$ in the nanomolar range and the well known fact that gastric mucosal cells synthesize prostaglandins, mainly $\mathrm{PGE}_{2}$ and $\mathrm{PGI}_{2}$, ${ }^{32}$ we conclude that E-type prostaglandins may be involved in the physiological regulation of mucus production in the stomach in vivo, whereas prostacyclin may have other targets for action for example, gastric microcirculation. ${ }^{32}$

1 Neutra MR, Forstner JF. Gastrointestinal mucus: synthesis, secretion, and function. In: Johnson LR, ed. Physiology of the gastrointestinal tract. 2nd edition. New York: Raven Press, 1987: 975-1009.

2 Miller TA. Protective effects of prostaglandins against gastric mucosal damage: current knowledge and proposed mechanisms. Am F P hysiol 1983; 245: G601-23.

3 Heim H-K, Oestmann A, Thiele H, Sewing K-Fr. Incorporation of $\mathrm{N}$-acetyl- $\left[{ }^{14} \mathrm{C}\right] \mathrm{D}$-glucosamine and $\left[{ }^{3} \mathrm{H}\right] \mathrm{L}$-leucine by isolated pig gastric mucosal cells. Digestion 1989; 44: 26-35.

4 Mårdh S, Norberg L, Ljungström M, et al. Preparation of cells from pig gastric mucosa. Isolation of parietal cells by from pig gastric mucosa. Isolation of parietal cells by
isopycnic centrifugation on linear density gradients of isopycnic centrifugation on linear density
Percoll. Acta Physiol Scand 1984; 122: 607-13.

5 Winer BJ. Replicated experiments. In: Winer BJ, ed. Statistical principles in experimental design. New York: McGrawHill Book Co, 1971: 391-4.

6 Dunnett CW. A multiple comparison procedure for comparing several treatments with a control. F Am Statist Assoc 1955; 50: 1096-121.

7 Moncada S, Flower RJ, Vane JR. Prostaglandins, prostacyclin, thromboxane $\mathrm{A}_{2}$, and leukotrienes. In: Goodman Gilman A, Goodman LS, Rall TW, Murad F, eds. The pharmacological basis of therapeutics. 7th edition. New York: Macmillan Publishing Co 1985: 660-73.

8 Robertson RP. Characterization and regulation of prostaglandin and leukotriene receptors: an overview. Prostaglandin and leukotriene rece
glandins 1986; 31: 395-411.

9 Coleman RA, Humphrey PPA, Kennedy I, Lumley P. Prostanoid receptors - the development of a working classification. TIPS 1984; 5: 303-6.

10 Johansson C, Aly A, Kollberg B, Rubio C, Erikoinen T, Helander HF. Trophic actions of oral $E_{2}$ prostaglandins on the rat gastrointestinal mucosa. Adv Prostaglandin Thromb oxane Leuk Res 1983; 12: 403-7.

11 Gilbertson TJ, Ruwart MJ, Stryd RP, et al. Partial charac terization of the gastrointestinal weight changes produced in the female rat by 16,16-dimethylprostaglandin $\mathrm{E}_{2}$. Prostaglandins 1983; 26: 745-59.

12 Reinhart WH, Müller $\mathrm{O}$, Halter F. Influence of long-term 16,16 -dimethyl prostaglandin $E_{2}$ treatment on the rat gastrointestinal mucosa. Gastroenterology 1983; 85: 1003-10.

13 Dembinski A, Konturek SJ. Effects of E, F, and I series prostaglandins and analogues on growth of gastroduodenal mucosa and pancreas. Am $\mathcal{F}$ Physiol 1985; 248: G170-5.

14 Bersimbaev RI, Tairov MM, Salganik RI. Biochemical mechanisms of regulation of mucus secretion by prostaglandin $E_{2}$ in rat gastric mucosa. Eurf Pharmacol 1985; 115: 
15 Terano A, Ivey KJ, Stachura J, et al. Cell culture of rat gastric fundic mucosa. Gastroenterology 1982; 83: 1280-91.

16 Terano A, Hiraishi H, Ota S, Sugimoto T. Arachidonic acid stimulation of mucus production by rat gastric cultured cells. Dig Dis Sci 1987; 32: 878-82.

17 Seidler U, Knafla K, Kownatzki R, Sewing K-Fr. Effects of endogenous and exogenous prostaglandins on glycoprotein synthesis and secretion in isolated rabbit gastric mucosa. Gastroenterology 1988; 95: 945-51.

18 Jentjens T, Smits HL, Strous GJ. 16,16-dimethyl prostaglandin $\mathrm{E}_{2}$ stimulates galactose and glucosamine but not glandin $\mathbf{E}_{2}$ stimulates galactose and glucosamine but not
serine incorporation in rat gastric mucous cells. Gastroenterology 1984; 87: 409-16.

19 Tsukada H, Zielenski J, Mizuta K, Slomiany BL, Slomiany A. Prostaglandin protection against ethanol-induced gastric injury: regulatory effect on the mucus glycoprotein metabolism. Digestion 1987; 36: 201-12.

20 Beinborn M, Netz S, Staar U, Sewing K-Fr. Enrichment and characterization of specific $\left[{ }^{3} \mathrm{H}\right] \mathrm{PGE}_{2}$ binding sites in the porcine gastric mucosa. Eur 7 Pharmacol 1988; 147: 217-26.

21 Tepperman BL, Soper BD. Subcellular distribution of $\left[{ }^{3} \mathrm{H}\right]$ prostaglandin $\mathrm{E}_{2}$ binding sites in porcine gastric mucosa. prostaglandin $\mathrm{E}_{2}$ binding sites

22 Woo SK, Roszkowski AP, Waterbury LD, Garay GL. Gastric mucosal binding studies with enprostil: a potent anti-ulcer mucosal binding studies with enprostil: a pote

23 Tsai BS, Kessler LK, Schoenhard G, Collins PW, Bauer RF Demonstration of specific E-type prostaglandin receptor using enriched preparations of canine parietal cells and $\left[{ }^{3} \mathrm{H}\right]$ misoprostol free acid. Am $\mathcal{F}$ Med 1987; 83 (suppl IA) 9-14.
24 Hennies S, Sewing K-Fr. In porcine fundic mucosa prostaglandin $\mathrm{F}_{2,}$ binds exclusively to the prostaglandin $\mathrm{E}_{2}$ receptor. Naunyn-Schmiedeberg's Arch Pharmacol 1987; 335 R41.

25 Tepperman BL, Soper BD, Emery SK. Specific binding of a stable prostacyclin analogue (iloprost) to rat oxyntic mucosa. Prostaglandins 1984; 28: 477-84.

26 Beinborn M, Kromer W, Staar U, Sewing K-Fr. Binding of ${ }^{3} \mathrm{H}$-iloprost to rat gastric mucosa: a pitfall in performing radioligand binding assays. Res Commun Chem Pathol Pharmacol $1985 ; 49: 337-51$.

27 Johansson C, Uribe A, Rubio C, Isenberg JI. Effect of ora prostaglandin $E_{2}$ on DNA turnover in gastric and intestina epithelia of the rat. Eur $\mathcal{F}$ Clin Invest 1986; 16: 509-14.

28 Miller TA, Gum ET, Guinn EJ, Henagan JM. Prostaglandin prevents alterations in DNA, RNA, and protein in damaged gastric mucosa. Dig Dis Sci 1982; 27: 776-81.

29 Konturek SJ, Radecki T, Brzozowski T, et al. Gastric cytoprotection by epidermal growth factor. Role of endogenous prostaglandins and DNA synthesis. Gastroenterology 1981; 81: 438-43.

30 Fich A, Arber N, Sestieri M, Zajicek G, Rachmilewitz D. Effect of misoprostol and cimetidine on gastric cell labeling Effect of misoprostol and cimetidine on

31 Raufman J-P, Cosowsky L. Relation of prostaglandin-induced increases in cellular cAMP to stimulation of pepsinogen increases in cellular cAMP to stimulation of pepsinogen secretio

32 Whittle BJR, Vane JR. Prostanoids as regulators of gastrointestinal function. In: Johnson LR, ed. Physiology of the gastrointestinal tract. 2nd edition. New York: Raven Press, 1987: 143-80. 